\title{
The Analysis of Code Mixing Used by Agnez Monica in Commentating the Participants of The Voice Indonesia Contest
}

\author{
Paulina Novarita \\ Islamic University of Nusantara \\ Faculity of teaching and training \\ English Teaching Departement \\ Soekarno Hatta Street No. 530, \\ Bandung, West Java, Indonesia
}

\begin{abstract}
The title of this research is "The Analysis Of Code Mixing Used By Agnez Monica In Commentating The Participants Of The Voice Indonesia Contest". The research intended to figure out why Agnez Monica did code-mixing when she commented the participant in the voice Indonesia contest. The research applied qualitative method to investigate the types of code-mixing and the reasons for doing code-mixing. The data were taken from video that are published in youtube. The comments selected were mainly focused on technique vocal. The data analysis reveals that code-mixing is mostly found when someone talked about music, art and some comment about vocal technique.
\end{abstract}

Keywords: code mixing, the voice Indonesia, Agnez Monica, Commentating

\section{Introduction}

According to Hammers and Blanc, code mixing is a strategy ofcommunication used by speakers of a language who transfer elements or rules from other language to their own language. In the same way, code mixing is defined as a system of signs which we use to communicate with each other (David and Rebecca, 2007:1).

According to the researcher observation that code mixing is formed from two languages or more that is used by someone when they are speaking. In fact, this situation of bilingualism is presented in every country, in all classes of society and at all age levels (Grosjean, 1982). This research analyzes the used of code mixing by Agnez Monica as a judge in the voice Indonesia contest. Commonly, code mixing occur in our everyday life and we can find it also in every shows that is presented by our television channel such as in entertainment news, advertisement, even in music competition. According to the title of this research, the research is going to figure out how oftencode mixing used by agnez monnica as a judge, to comment the participant in music conpetition and what types of code mixing that usually appears in her comment.

Nowadays every people mix their language in order to blend with their environement or even to be popular among their society. According to Grosjean (1982) bilingualism happen at all age levels. The researcher interests to obeserve the phenomenon of code mixing in music competition especially the one that is adapted from the western contest that maybe become one of the reasons why the judges usually use code mixing in every their comment, so in this case code mixing is extremely produced by the judges so that the participant should understand.

There are three types of code mixing and later those types will be percentage in order to see the final result by counting the numbers of type that is used most in the utterance.

According to the explanation above, the researcher form the question to build this research. In this study, the researcher formulates the problems as follow:

1. What types of code mixing are found in Agnes Monica's comments for the participats of the voice Indonesia?

2. For what reasons are the code mixing used?

In line with those research questions, the research also formulates the purpose of the research as follow :

1. To observe the types of code mixing used by Agnes Monica as one of the commentators or the judges.

2. To analyze the reasons of using code mixing between multilingual societies.

According to that formulation above, the researcher considers the title of this research as the analysis of code mixing used by Agnez Monica in commentating the participants of The Voice Indonesia contest. 


\section{Research Methodology}

For conducting this research, it is important for a researcher to determine the research method that would like to use. A method is a kind of systematical work plan in order to make the research work become easier, so that it can achieve its main purpose (Sudaryanto, 1993:9). Arranging the research method is the initial step before doing the process of collecting data and analyzing them.

The method of this research is selected by considering its appropriateness with the research object. In this case, the object determinates the method, not in the other hand. This research method is arranged based on the problem analyzed and the main purpose of the research. In this chapter, the writer will discuss a research approach, population and sample, unit of analysis, method of collecting the data, method of analyzing the data and method of presenting the data.

\subsection{Research Approach}

The research design of this research is descriptive qualitative method since it provides a systematic, factual, and accurate description of a situation of area (Issac and Michael, 1987:42). Beside descriptive method, the researcher also applies qualitative method. This method is based on the data which are words and not about the number (Sudaryanto, 1993:62). It is called as qualitative method, since the collected data are in the forms of sentence. The research is conducted by qualitative approach because the result of the data analyzed is in descriptive phenomenon such as words, sentence and utterance. In this research, the researcher will describe the type of code mixing of each statement as utterance in the video of Agnez Monica comment in the voice indonesia, and give explanation about the motive in order to know the reasons why the occurrence of code mixing.

\subsection{Population and Sample}

Rahardi (2001:8) differentiates the data source into two categories i.e. Primary data and secondary data. Primary data is the data gained directly from the source meanwhile secondary data is the one gained indirectly. In this research, the reseracher has the primary data from the source that is the Agnez Monica video when giving comment to the participants of the voice Indonesiaas her research object.

According to Koentjaraningrat (1997:115), population is the whole research data. In this case, the population of this research is all statements or utterances that contain code mixing in the Agnez Monica video when giving comment to the participants of the voice Indonesia.

After having population, the researcher takes the sample. Nawawi (1998:144) defines sample as a part of population that is the source of the research data. According to Singarimbun and his friends (1989:155), there are two techniques in taking sample namely purposive random sampling and purposive sampling.

In conducting the research, the researcher uses purposive sampling technique. The chosen sample absolutely has the characteristics of code switching and code mixing. In this research, the researcher takes the sentence or utterance samples which shows the different types and reasons of code switching and code mixing clearly. As a result, there are thirty data of utterance in the Agnez Monica video when giving comment to the participants of the voice Indonesiaas sample that will be analyzed in detail.

\subsection{Unit of Analysis}

Unit of analysis on this research is one statement that is spoken by the Agnez Monica video when giving comment to the participants of the voice Indonesia. The realization of the data can be a word, a clause, a clause complex, or a sentence in one conversation.

\subsection{Method of Collecting the Data}

In collecting the data, the writer uses the technique from Sudaryanto (1993:134) that is Simak Bebas Libat Cakap technique. In this technique, the researcher do not get involved directly in the dialogues produced by the characters in the Teenlit. What the writer apply is reading and observing the conversations in the teenlit. Then, she uses note-taking technique based on the theory of Sudaryanto (1993:135). The researcher tries to take a note on the statements or utterances that is produced by the Agnez Monica video when giving comment to the participants of the voice Indonesia. Some other statements or utterances that are in English or Indonesian only are excluded because they do not contain language switching and mixing.

\subsection{Method of Analyzing the Data}

After gaining and collecting the data, the researcher takes the next step that is analyzing the data. The method of analyzing data that is used in this research is Sudaryanto's Translational (identity) Method that is one of sub unit in Padan Method (Sudaryanto, 1993:15). 
Padan method is research method which its determiner device is outside of language, apart from and does not become part of the language which researched (Sudaryanto' 1993:13). The researcher uses the padan method to analyze type and reason of code mixing. While the writer uses padan method in analyzing type and reason because she uses the story background of the characters in the teenlit to analyze the type and reason.

The technique in padan method consists of basic technique which is called pilah unsur tertentu. The determiner device is daya pilah which is about the mental of the speaker. Daya pilah can be divided into five which are referential daya pilah, phonetic articulator daya pilah, translational daya pilah, orthography daya pilah, and pragmatist daya pilah ( Sudaryanto:

1993:21).

In the use of padan method, the basic technique which is chosen by the researcher is translational daya pilah, since the objects of the discussion are elements of Sociolinguistic, especially code switching and code mixing which use the other langue as the determining tool.

The steps that the researcher takes in analyzing the data are as follows:

1. Watching the whole Agnez Monica video when giving comment to the participants of the voice Indonesia.

2. Choosing the statements or utterances which have the characteristics of code mixing

3. Classifying the data based on the types and the reason of the use of code switching and code mixing. The analysis uses the 6 types of code mixing based on Hoffman's theory and the 10 reasons why the Agnez Monica video when giving comment to the participants of the voice Indonesiamix or switch their language based on Hoffman and Saville Troike's theory.

4. Describing the types and the reasons of code mixing sample that are found in the Agnez Monica video when giving comment to the participants of the voice Indonesia.

5. Drawing Conclusion

\section{Literary Review}

\subsection{Code mixing}

Code mixing is a mixing of two codes or languages, usually without a change of topic. Code mixing often occurs within one sentence, one element is spoken in language A and the rest in language B. In addition, Nababan (1993:32) said that code mixing is found mainly in informal interactions. In formal situation, the speaker tends to mix it because there is no exact idiom in that language, so it is necessary to use words or idioms from other language.

At least, the phenomenon of bilingualism results in the occurrence of code switching and code mixing (Wardaugh, 1986:101). It happens when a speaker requires a particular code, in order to switch or mix one code to another and even create a new code in process (Wardaugh, 1986:101). Hoffman (1991: 104) then, maintains that code mixing is the switches occurring within a sentence.

The example is the mixing between Malay - English:

"This morning I hanter my baby tu dekat babysitter tu lah."

(This morning I took my baby to the babysitter). Stockwell (2002: 137)

\subsection{Type of code mixing}

1. Intra-sentential switching / code mixing

This kind of code mixing occurs within a phrase, a clause or a sentence boundary, as when a Spain-English bilingual says: "I started going like this. Y luego decla (and then he said), look at the smoke coming out my fingers."

Another example is from Wardaugh (1986:108) "Estaba training para pelar": "He was training to fight."

2. Intra-lexical code mixing

This kind of code mixing which occurs within a word boundary, such as in shoppa (English shop with the Panjabi plural ending) or kuenjoy (English enjoy with the Swahili prefix $k u$, meaning 'to').

3. Involving a change of pronunciation

This kind of code mixing occurs at the phonological level, as when Indonesian people say an English word, but modify it to Indonesian phonological structure. For instance, the word 'strawberry' is said to be 'stroberi' by Indonesian people.

\subsection{Reason to use code switching}

In general, code mixing happens in every part of our speech because of several factors and personal reasons. In the same way code mixing is produced in our speech because of our background such as profession, environment and the skill of speaking in more than one language so that we have to consider why people use code switching in their speech. 
According to Luke (2015), he stated that code mixing is used in particular topics such as jokes and some comments about political leaders. Thus, the results can provide insights for Parata Ndaya members to build awareness on preserving their local language (i.e. Pamona language) as well as to enhance solidarity among members of the group site.

Hoffman (1991:116) in his research stated that there are several reasons why do people use code mixing in their speech, such as :

1. Talking about a particular topic

People sometimes prefer to talk about a particular topic in one language rather than in another. Sometimes, a speaker feels free and more comfortable to express their emotional feelings in a language that is not their everyday language.

2. Being emphatic about something

Usually, when someone who is talking using a language that is not his native tongue suddenly wants to be emphatic about something, he/she, either intentionally or unintentionally, will mix from his second language to their second language. Or, on the other hand, there are some cases where people feel more convenient to be emphatic in their second language rather than in their first language.

3. Repetition used for clarification

When a bilingual wants to clarify their speech so that it will be understood more by the listener, they can sometimes use both of the languages that he masters saying the same utterance (the utterance is said repeatedly).

4. Expressing group identity

Code mixing can also be used to express group identity. As it has been mentioned previously, the way of communication of academic people in their disciplinary groupings, are obviously different from other groups. In other words, the way of communication of one community is different from the people who are out of the community (Barnett, $1994:$ 7).

\section{Research Finding}

This finding represents the result of the analysis the types of code mixing that has been found and the following reasons why code mixing is often used by Agnes Monica. Asmentioned before, the types of code mixing are divided into three types: intrasentential mixing, intra lexical mixing, and involving a change ofpronunciation.

In this study, in analyzing the code mixing, the researcher tried to find some types of code mixing and the following reasons why code mixing occured in Agnes Monica's comment.

\subsection{Types of English-Indonesian Code Mixing}

a) Intra Sentential Mixing

\begin{tabular}{|l|l|}
\hline No & Utterances \\
\hline & Paling hanya butuh sedikit push aja supaya amunisinya lengkap gitu. \\
\hline & Tapi, that was beautiful. \\
\hline & Satu hal adalah, masalah stage performance. \\
\hline & Karena biar gimana, the reality is orang-orang nonton performance kamu, ga cuma denger. \\
\hline & Kamu mau sama siapa aja, itu pilihan kamu. Tapi, you are really really good. \\
\hline & Kamu bisa jadi penyanyi yang lengkap dan juga performer yang lengkap. \\
\hline & Stageperformancenya juga captivating gitu loh. \\
\hline & $\begin{array}{l}\text { Suara kamu istilahnya kalo secara karakter bukan karakter yang terlalu jauh tapi kamu straight } \\
\text { forward aja simple tapi enak. }\end{array}$ \\
\hline & Kamu harus jadi diri kamu sendiri yang bisa ngasih point of view yang berbeda. \\
\hline & Tapi pada akhrinya jadi boring kamu jadi Judika kedua. \\
\hline & Awalnya kamu magical. \\
\hline & Nah, itu nervous di situ ada triknya. \\
\hline & Kan kalo lagu beat kita bisa hajar terus gitukan. \\
\hline & Yang harus controlled banget kan. \\
\hline & Itu apa ya, intimate gitu. \\
\hline & Tapi, meaningful. \\
\hline & Tapi kalo misalnya tadi saya liat kamu lebih banyak bermain di chest voice and head voice. \\
\hline $\begin{array}{l}\text { Kamu harus bisa catch attention bukan hanya dari suara kamu tapi juga dari stage performance } \\
\text { kamu }\end{array}$ \\
\hline Tapi keren banget over all. \\
\hline Itu namanya bukan complete yourself justru harus explore dari point of view yang berbeda. \\
\hline Kita harus fair dong. \\
\hline
\end{tabular}


b) Intra lexical mixing

\begin{tabular}{|l|l|}
\hline No & Utterances \\
\hline & $\begin{array}{l}\text { Saya bisa bagiin ke kamu tips-tipsnya seperti apa dan stage performance kamu bisa } \\
\text { dipush lagi. }\end{array}$ \\
\hline & Gimana kalo misalnya kamu bisa mainin dihasty \\
\hline
\end{tabular}

c) Involving a change of pronunciation

\begin{tabular}{|l|l|}
\hline No & Involving a change of pronunciation \\
\hline & $\begin{array}{l}\text { Kamu stabil, improvenya rapi, tidak emosional saat menyanyi, tapi feelingnya } \\
\text { dapet. }\end{array}$ \\
\hline & Terus ngambil-ngambilnya, improvenya, teknik vokal nya juga kamu ada. \\
\hline & Dia berani mengeluarkan energinya dia \\
\hline & Saya punya kriteria-kriteria, elemen-elemen yang saya perlu \\
\hline & $\begin{array}{l}\text { Itu namanya bukan complete yourself justru harus explore dari point of view yang } \\
\text { berbeda. }\end{array}$ \\
\hline & Nah, itu nervous di situ ada triknya. \\
\hline & Jadi pada akhirnya lebih seksi ya. \\
\hline
\end{tabular}

Those were all the classification types of code mixing used by Agnes Monica in commentating the participant of The Voice Indonesia contest. There were three types for code mixing, they were intra sentential mixing and involving a change of pronunciation and intralexical mixing.

From those several types of code mixing used by the commentator indicates that an attempt to comment the participants with his virtuosity in English or at least in one prestige language. It is the one of commentator's creativity in commentating to comment the performance of the participants. She is the international singer who has accustomed using English, so she mixed two languages in commentating the participants of The Voice Indonesia contest.

\subsection{The Reasons of Using Code Mixing}

After analyzing and classifying the types of code mixing, the researcher identified the following reasons why Agnes Monica used these English-Indonesian codes mixing in commentating the participant of The Voice Indonesia contest. Several utterances of comments were used for more than one reason. It was caused of the utterances had multi meanings.

\section{a. Talking about particular topic}

1) Satu hal adalah, masalah stage performance.

2) Kamu harus bisa catch attention bukan hanya dari suara kamu tapi juga dari stage performance kamu.

3) Saya punya kriteria-kriteria, elemen-elemen yang saya perlu

4) Kamu bisa jadi penyanyi yang lengkap dan juga performer yang lengkap.

5) Karena biar gimana, the reality is orang-orang nonton performance kamu, ga cuma denger.

6) Nah, itu nervous di situ ada triknya.

From the examples above, the bold words were such examples of talking certain topic reasons. The sentencens were mixed with English because Agnes Monica talked about specific topic-that is about performance. Those terms are familiar in field of life performance.

b. Being Emphatic

1) Tapi, meaningful.

2) Itu apa ya, intimate gitu.

3) Awalnya kamu magical.

4) Suara kamu istilahnya kalo secara karakter bukan karakter yang terlalu jauh tapi kamu straight forward aja simple tapi enak.

5) Stageperformancenya juga captivating gitu loh.

6) Tapi, that was beautiful. 
From the example above, the word 'meaningful', 'intimate', 'magical', 'straightforward', and 'captivating' wereconveyed because of Agnes Monica intentionally mixed her first language (Indonesian) to her second language (English). It was also causedshe felt more convenient to compliment the participants by those words.

\section{c. Repetition used for clarification}

1) Kamu mau sama siapa aja, itu pilihan kamu. Tapi, you are really really good.

2) Tapi keren banget over all.

3) Tapi pada akhrinya jadi boring kamu jadi Judika kedua.

4) Gimana kalo misalnya kamu bisa mainin dihasty.

5) Kamu stabil, improvenya rapi, tidak emosional saat menyanyi, tapi feelingnya dapet.

From the examples above, the bold words or sentenceswere mixed in English for commentating the participants. Agnes Monica wanted to repeat the same words in English which had been spoken in the previous words for emphasizing her compliments.Agnes Monica wanted to make the content of her comment runs smoothly and can be understood by the listener although it was said in English.

\section{d. Expressing group identity}

1) Tapi kalo misalnya tadi saya liat kamu lebih banyak bermain di chest voice and head voice.

2) Terus ngambil-ngambilnya, improvenya, teknik vokal nya juga kamu ada. From the examples above, Agnes Monica wanted to show her group identity as an expert singer because those terms were identifically understood by the expert singer and mucisian.

\section{Conclution}

Having collected and analyzing the data, some conclusions were given below: All types of code mixing used in The Voice IndonesiaContest namely: intra sentential mixing, intra lexical mixing and involving a change of pronunciation. It consisted of 43/552 X 100\% utterance (7.78\%) Intra Sentential Mixing, 2/552 X 100\%, utterances (0.36\%) Intra Lexical Mixing, and 8/552 X 100\% utterances (1.44\%) Involving a change of pronunciation. The result showed that the most dominant type of code-mixing used byAgnes Monicais intra sentential mixing. Intra sentential mixing was the most dominant in Agnes Monica's comments because she codes mix in English unconciously. Thus most of the code mixing occured in words, phrases, and short sentences.

Code mixing is also showing the identity of someone who produce it. In this research, the researcher found several reasons from Agnez Monica using the code mixing in commentating the participant. The reasons are to speak the particular topics, in this case the topic is around the art field, to convey special emotion towards the participants of the contest, to repeat her comment in order to give the clarification, to express the group identity, and of course to criticize. Regarding to her background of her profession as an international singer, it is possible that she probably uses code mixing. And by seeing this show is adapted from the international contest, so it will be a benefit for the judges to mix their language to the international language, that is English.

\section{References}

Grosjean, F. (1982). Life with Two Languages: An Introduction to Bilingualism. Cambridge, Mass: Harvard University Press.

Hammers, Josiane F, andMichel HA. Blanc. (1990). Bilinguality and Bilingualism. New York : Cambridge University

Harris, Michael. (2000). Human Resources Management: Practical Approach, 2ndEdition. The Dryden Press

Hoffman, C. (1991). An Introduction to Bilingualism. New York: Longman

Isaac, S., \& Michael, W.B. (1981). Handbook in Research and Evaluation. California: Edits Publishers

Koentjaraningrat, Prof. Dr.(1997). Pengantar Ilmu Antropologi.Jakarta : PT Rineka Cipta

Nawawi. (2011).Manajemen Sumber Daya Manusia: Untuk Bisnis Yang Kompetitif. Gajahmada University Press, Yogyakarta

Singarimbun, Masri dan Sofian Effendi. (1989). Metode Penelitian Survey. LP3ES, Jakarta.

Stockwell, Peter. (2002). Resource book for students. London:Routledge.

Sudaryanto. (1993).Metode dan Aneka Teknik Analisis Bahasa. Sanata Dharma University press, Yogyakarta

Wardhaugh, Ronald. (1986). An Introduction to Sociolinguistics. Oxford: Basil Blackwell 